\title{
The Impact Of Performance Expectation Gap On Corporate Strategic Change-Evidence from Listed Companies in the IT Industry
}

\author{
Luyao Huangfu ${ }^{1}$, Fang Wang ${ }^{1}$, Dan $\mathrm{Liu}^{1}$, Nan $\mathrm{Wu}^{1}$ \\ ${ }^{1}$ School of Management, Shandong Technology and Business University, Yantai, China. \\ Correspondence: Dan Liu, School of Management, Shandong Technology and Business University, Yantai, \\ China.
}

Received: September 17, 2021

Accepted: October 14, 2021

Online Published: October 19, 2021

doi:10.5539/ibr.v14n11p46

URL: https://doi.org/10.5539/ibr.v14n11p46

\begin{abstract}
Based on the panel data of Chinese listed companies in the information technology industry from 2007 to 2018 , this paper uses a fixed-effect model to study the relationship between corporate performance expectation gap and strategic change and analyzes the moderating effect of private benefits of management control and equity incentive. It is found that the greater the gap between corporate performance expectations is, the lower the frequency of corporate mergers and acquisitions is, and the higher the frequency of corporate asset divestment is. Further research finds that private benefits of management control weaken the positive correlation between corporate performance expectation gap and asset stripping frequency. Equity incentive strengthens the negative correlation between corporate performance expectation gap and corporate mergers and acquisitions frequency, and the positive correlation between corporate performance expectation gap and corporate asset stripping frequency. Based on this, when enterprises carry out strategic change, enterprises should choose the direction of strategic change according to the degree of performance expectation gap, and promote the effective realization of strategic change by improving the governance of the board of directors and optimizing the management incentive mechanism.
\end{abstract}

Keywords: performance expectations gap, strategic change, private benefits of control, equity incentive

\section{Introduction}

Strategic change is the behavior of enterprises to respond to market changes and fierce competition. Factors affecting corporate strategic change behavior include internal and external aspects. Although non-marketized strategic behavior can highlight the unique significance contained in the current domestic economic transformation, it is precisely because of this particularity that it may reduce the universality of research conclusions and the extensive guidance of research results (Peng, 2003). Therefore, it is necessary to study the market-oriented strategic behavior. The performance expectation and performance feedback of enterprises are important perspectives for analyzing strategic behavior such as enterprise change (Kim \& Rhee, 2017).

Strategic change decisions are influenced by both enterprise and key individuals such as management. Taking into account the characteristics, psychology, cognition, and motivation of management in strategic change is an essential part of the in-depth study of strategic change (Quigley \& Hambrick 2012; del Carmen Triana, Richard, $\& \mathrm{Su}, 2019)$. In the decision-making of enterprise strategic change, the management will inevitably consider their interests and use their powers to seek private benefits for themselves. When the management is more likely to seek private benefits of control, the more likely it is to take risky behavior to make itself gain more benefits (D'Souza \& Nash, 2017; Muravyev, Berezinets, \& Ilina, 2014; Hope, Wu, \& Zhao, 2017). Equity incentive can make the interests of management, enterprises, and shareholders tend to be consistent, making it a 'Community of a Shared Future', sharing revenue and sharing risks (Jayaraman \& Milbourn, 2015; Hass, Tarsalewska, \& Zhan, 2016; Armstrong, Larcker, Ormazabal, \& Taylor, 2013).

Based on the enterprise behavior theory and principal-agent theory, this paper considers the influence of key individual management in the performance feedback model (the performance evaluated is the financial), to explore the selection of enterprise strategic change modes under different performance expectation gaps and the moderating effect of management. This paper mainly studies the following three aspects: How does the gap of corporate performance expectations affect the choice of strategic change (M\&A or asset stripping)? Second, how do private benefits of management control affect the relationship between corporate performance expectations 
gap and strategic change? Third, how does managerial equity incentive affect the relationship between corporate performance expectations gap and strategic change?

The contributions of this paper are mainly the following two points. First, this paper combines the principal-agent theory and the corporate behavior theory to explore the moderating effect of management on the relationship between the gap in corporate performance expectations and strategic change. It broadens the theoretical factors that need to be considered in corporate strategic change under the performance feedback model, and takes into account the behavior of key individuals in internal factors in corporate strategic change.

\section{Literature Review}

\subsection{Performance Expectation Gap and Strategic Change}

According to the theory of corporate behavior, decision-makers under the constraint of bounded rationality usually determine a target value for the current enterprise according to the past performance level of the enterprise or the performance level of industry competitors, namely the expected value of performance (March, 1963). Performance expectation is an important reference point for enterprise strategic decision-making, and decision-makers will compare the difference between performance expectation and actual performance at the end of the period as the basis for strategic adjustment (Jordan \& Audia, 2012). When the actual performance of the enterprise is lower than the expected performance, that is, when the enterprise is in a state of performance expectation gap, managers will be under pressure from stakeholders, triggering the problem search mechanism and trying to find solutions through strategic change (Oehmichen, Schrapp, \& Wolff, 2017; Herrmann \& Nadkarni, 2014).

Most literature on corporate strategic change from the perspective of corporate behavior theory does not distinguish the differences in the direction of strategic change. There are obvious differences in the level of resource input and the degree of risk-taking in different directions of strategic change. Whether an enterprise will change its strategic behavior and what kind of strategic change it will take mainly depends on how the management evaluates the suitability of the change plan to solve the current problems. One of the core determinants of this evaluation is the gap between actual performance and expected performance. The greater the gap in performance expectations, the higher the probability of risk-taking behavior, the more likely to adopt a strategy of intense change. Strategic change approaches that apply to addressing smaller performance expectations gaps may not be appropriate to address larger performance expectations gaps and vice versa. When the actual performance of the enterprise is lower than the expected performance, the enterprise may improve the performance level through strategic change. When the performance expectation gap expands, the motivation of strategic change will increase (Lant, Milliken, \& Batra, 1992).

When there is a large gap in corporate performance expectations, it often means that companies bear large losses and face severe resource constraints (Audia \& Greve, 2006). At this time, enterprises are more inclined to choose an asset divestiture strategy that releases resources and reduces the implementation of an M\&A strategy that consumes a lot of resources (Iyer \& Miller, 2008). With the narrowing of the gap between corporate performance expectations, the possibility of asset divestiture will decrease. When the corporate performance expectation gap is small, it is more likely to choose the M\&A strategy that consumes a lot of resources compared with the enterprises with a large gap. With the expansion of the gap between performance expectations, the possibility of M\&A by enterprises to deal with insufficient performance will become smaller and smaller. The lower the actual performance of enterprises is, the less likely it is to carry out M\&A. Kuusela and Maula (2017), Masoud ( (2017) found that in the state of performance expectation gap, when the performance level is relatively close to expectations and the financial situation is good, enterprises will increase reform through mergers and acquisitions. When the performance is far from expectations and the financial situation is poor, enterprises will choose asset divestiture to increase strategic change. Based on this, this paper puts forward the following assumptions :

Hypothesis 1a: Corporate performance expectations gap is negatively correlated with the frequency of mergers and acquisitions.

Hypothesis $1 \mathrm{~b}$ : The degree of corporate performance expectation gap is positively correlated with the frequency of asset divestment.

\subsection{Private Benefits of Management Control as a Moderator Variable}

The strategic behavior of enterprises is affected by individuals and enterprises. We should not only consider the enterprise level but also understand the influence of key individuals on the strategic behavior of enterprises (Shimizu, 2007). According to the principal-agent theory, under the modern corporate governance structure of 
separation of ownership and management rights, there is a conflict of interest between management and shareholders. Management may violate the wishes of shareholders and use their authority to seek private benefits. Chinese enterprises, especially state-owned enterprises, generally have the phenomenon of owner absence. Corporate control is in the hands of managers, and the self-interest of management control is more prominent. Wang and $\mathrm{Wu}(2020)$ believe that managers with actual control and information advantages will try to seek private benefits of control for themselves, because the losses caused by enterprises do not require managers who do not hold or hold a minority stake in the enterprise. Sauerwald, Heugens, Turturea and Van Essen (2012) found that management launched multiple acquisitions mainly to seek private benefits of control, the frequency of mergers and acquisitions and on-the-job consumption levels were significantly positively correlated._Zhang, Liang and Sun (2013) believes that due to the regulation of management compensation in Chinese enterprises, and on-the-job consumption has become an additional compensation for management without external disclosure, it is more concealed and will not be regulated by the government, so management is likely to seek private benefits through on-the-job consumption.

In summary, managers who have actual control rights and information advantages are likely to conflict with the interests of enterprises and shareholders for self-interest. Because management pay is regulated, non-monetary private benefits are more favored by management, such as covert on-the-job consumption, with neither explicit contracts as a guarantee nor too high supervision costs. The expansion of the scale of enterprises can hide the real reason for the increase in on-the-job consumption, so frequent mergers and acquisitions become an effective way for managers to seek non-monetary private benefits. On the contrary, in order to prevent the reduction of non-monetary private benefits, the management will resist the divestiture behavior that reduces the scale of enterprises. Therefore, when enterprises are in a state of the performance gap, the management is more willing to take risks to initiate mergers and acquisitions or retain departments with poor performance for self-interest reasons. Based on this, this paper puts forward the following hypothesis:

Hypothesis 2a: Private benefits of management control weaken the negative correlation between the degree of corporate performance expectations gap and the frequency of mergers and acquisitions.

Hypothesis $2 \mathrm{~b}$ : Private benefits of management control positively moderates the positive correlation between corporate performance expectation gap and asset stripping frequency.

\subsection{Management Equity Incentive as Moderating Variable}

According to the principal-agent theory, managers often make decisions that damage the interests of enterprises and shareholders because of self-interest. It is of great significance to motivate management in a certain way to make the interests of management and shareholders and enterprises converge. The flexible incentive beyond fixed salary is equity incentive, which can connect the interests of management and enterprises, and help to solve the conflict of interest between owners and operators under the separation of two rights. Kim, Boyd, Kim and Cheong (2016) found that the implementation of equity incentives to management can make management have a stronger sense of mission and responsibility, pay more attention to the future development strategy of enterprises in decision-making, help to achieve win-win with shareholders and the board of directors, and avoid self-interest behavior that undermines the interests of enterprises. Hung, Liu and Tsai (2012) found that when the actual performance of the enterprise is higher than the expected performance, equity incentive is positively correlated with management risk-taking. On the contrary, when the actual performance of the enterprise is lower than the expected performance, equity incentive is negatively correlated with management risk-taking.

According to corporate behavior theory, divestiture helps to unleash corporate resources, find more profitable and promising businesses, and provide companies with opportunities to reorient their current strategies (Berry, 2010; Markides, 1992). Divesting business sectors with poor performance usually has a positive impact on corporate earnings per share and asset returns. Equity incentive enables management to participate in corporate decision-making as shareholders and share risks and benefits with enterprises. When faced with poor performance, the choice of resource-consuming mergers and acquisitions will bear greater risk, stripping poor performance departments bear less risk. Therefore, in the face of performance gap management equity incentive is higher, the management tends to release resources of asset stripping behavior rather than consumption of resources of mergers and acquisitions. Based on this, this paper puts forward the following assumptions.

Hypothesis 3a: Equity incentive will strengthen the negative correlation between the degree of corporate performance expectation gap and the frequency of corporate M\&A.

Hypothesis $3 b$ : Equity incentive positively moderates the positive correlation between corporate performance expectation gap and corporate asset divestiture. 
Based on the above assumptions, this paper draws a research framework, as shown in Figure 1.

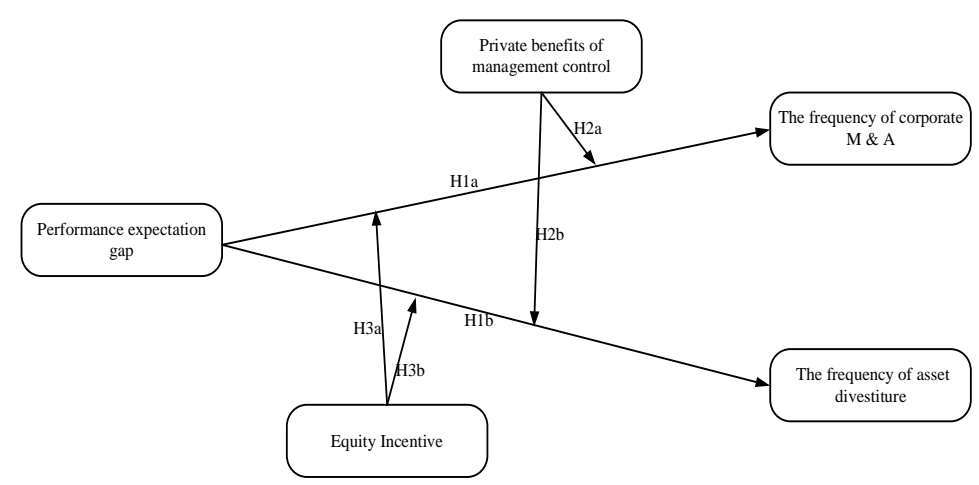

Figure 1. Research Model

\section{Research Method}

\subsection{Sample Selection and Data Source}

This paper selects Chinese information technology enterprises listed in Shanghai and Shenzhen A-shares from 2007 to 2018 as the research object. To reduce the potential impact of endogeneity, this paper makes a lag one-stage processing of explanatory variables. Therefore, the period of explanatory variables and control variables is 2007-2017, and the period of explained variables is 2008-2018. This paper finally obtains 2483 unbalanced panel data of 363 enterprises. This article data mainly comes from the Guotaian database, and through the enterprise annual report, Sina Financial Network, Chaochao information network information supplement. Stata 16.0 software was used for analysis.

\subsection{Variables Design}

\subsubsection{Strategic Change}

Strategic change can be divided into resource consumption and resource release. The former is measured by the frequency of annual asset M\&A, while the latter is measured by the frequency of annual asset stripping.

\subsubsection{Performance Expectations Gap}

Performance expectation gap refers to the gap between actual performance and expected performance. On the measurement of enterprise performance, this paper uses the return on assets, which is the most common in the related research of enterprise behavior theory, as the measurement index (Chen \& Miller, 2007).

Performance expectation gap can be divided into historical performance expectation gap and industry performance expectation gap. Referring to the literature of Kuusela et al. (2017), this paper selects historical and industry performance expectations to establish models respectively.

Historical performance expectations fall. The historical expectation of enterprises in this paper is calculated by the following formula :

$$
A_{t}=\alpha P_{t-1}+(1-\alpha) A_{t-1}
$$

where $A_{t}$ represents the performance expectation of year $t, P_{t-1}$ represents the actual performance of year $t-1, A_{t-1}$ represents the performance expectation of year $t-1$, and $A_{0}$ represents the base year, namely the actual performance of enterprises in 2007.

Industry performance expectations fall. According to the theory of corporate behavior, performance comparisons are usually made with companies close to their strength, rather than with all other companies (Fiegenbaum \& Thomas, 1990; Fiegenbaum \& Thomas, 1995). Therefore, this paper uses Mahalanobis distance to determine enterprises with similar strength, hereinafter referred to as peer competitive enterprises, and calculates the average actual performance of peer competitive enterprises. According to the practice of Kuusela et al. (2017), the income and total assets of enterprises are selected as the specific indicators to reflect the strength of enterprises. The Mahalanobis distance between the enterprise and all other enterprises in the industry at the level of income and total assets is calculated by year, and $k$ closest enterprises are determined for each enterprise as 
peer competitors. The number of peer competitors adopted in the empirical test is 5 .

\subsubsection{Moderator Variable}

This paper takes the private benefits of management control and equity incentive as moderating variables.

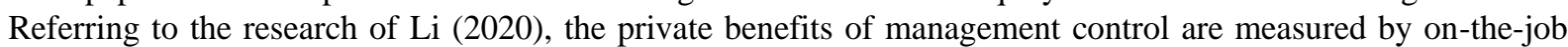
consumption, and the management cost adjusted by main business income is used to measure on-the-job consumption, to eliminate the influence of enterprise-scale and normal operating expenses on management cost. Equity incentive is measured by dividing the number of shares used by the enterprise to motivate the management by the total number of shares of the enterprise, to eliminate the influence of enterprise-scale and the total number of shares of the enterprise on equity incentive.

\subsubsection{Control Variable}

Due to the size of the enterprise and organizational redundancy resources affect the number of resources that enterprises can use, thereby affecting the ability of enterprises to carry out mergers and acquisitions and asset stripping, so this paper will scale and organizational redundancy as control variables. Referring to the research of Masoud (2017), the enterprise-scale is measured by the logarithm of the total assets of the enterprise, and the organizational redundancy is measured by the average value of the three indicators of the enterprise liquidity ratio, asset-liability ratio, and cost-income ratio.

Table 1. Explanation and explanation of variables

\begin{tabular}{|c|c|c|}
\hline Name & Symbol & Measurement \\
\hline $\begin{array}{l}\text { The frequency of } \\
\text { corporate M\&A }\end{array}$ & $A c q u i_{i, t}$ & Number of mergers and acquisitions declared by enterprises per accounting year \\
\hline $\begin{array}{l}\text { The frequency of asset } \\
\text { divestiture }\end{array}$ & Dives $_{i, t-1}$ & Number of spin-offs declared by enterprises per accounting year \\
\hline $\begin{array}{l}\text { Historical performance } \\
\text { expectations gap }\end{array}$ & Fallh $_{i, t-l}$ & $\begin{array}{l}\text { According to the recursive measurement method, the expected performance } \\
\text { expectation of the enterprise is subtracted from the actual performance, that is, the } \\
\text { historical performance expectation difference, and the surplus is } 0\end{array}$ \\
\hline $\begin{array}{l}\text { Industry performance } \\
\text { expectations gap }\end{array}$ & Falli $_{i, t-1}$ & $\begin{array}{l}\text { The absolute value of the difference between the average performance of an } \\
\text { enterprise and its reference enterprise is calculated by matching several peers of } \\
\text { similar size with Mahalanobis distance }\end{array}$ \\
\hline $\begin{array}{l}\text { Private benefits of } \\
\text { control }\end{array}$ & $\operatorname{Perk}_{i, t-1}$ & Management costs / main operating income for the year \\
\hline Equity incentive & Incen $_{i, t-1}$ & The ratio of the total number of equity incentive to the total number of shares \\
\hline Company scale & $\operatorname{size}_{i, t-1}$ & Logarithmic Measurement of Total Assets of Enterprises \\
\hline Firm age & Lnage $_{i, t-1}$ & Natural logarithm of enterprise establishment date \\
\hline Organizational slack & Slack $_{i, t-1}$ & $\begin{array}{l}\text { Measured by the mean of the three values of the enterprise flow ratio, asset-liability } \\
\text { ratio and cost-income ratio }\end{array}$ \\
\hline $\begin{array}{l}\text { Historical performance } \\
\text { expectation surplus }\end{array}$ & $A_{b o v h_{i, t-l}}$ & Calculated in the same way as historical expectations \\
\hline $\begin{array}{l}\text { Industry performance } \\
\text { expectation Surplus }\end{array}$ & $A_{b o v} v_{i, t-1}$ & The calculation is the same as expected \\
\hline Enterprise nature & state $_{i, t-1}$ & Value 1 when the final controller is state-owned, otherwise 0 \\
\hline Debt capital ratio & $\operatorname{Debt}_{i, t-1}$ & Ratio of total end-of-period liabilities to owners ' equity \\
\hline Free cash flow & freec $_{i, t-1}$ & $\begin{array}{l}\text { Control the impact of cash resources on enterprise strategy implementation. In } \\
\text { billions }\end{array}$ \\
\hline Ownership concentration & share $_{i, t-1}$ & proportion of the largest shareholder \\
\hline Year & year $_{i, t}$ & virtual variable \\
\hline
\end{tabular}




\subsection{Research Model}

Model 1: To test the relationship between corporate performance expectation gap (including corporate historical performance expectation and industry performance expectation, the same below) and corporate M\&A frequency, this paper refers to the Kuusela model and establishes the following model:

$$
\begin{gathered}
\text { Acqui }_{i, t}=\beta_{0}+\beta_{1} \text { Fallh }_{i, t-1}+\sum \text { Control }+\varepsilon_{i, t} \\
\text { Acqui }_{i, t}=\beta_{0}+\beta_{1} \text { Falli }_{i, t-1}+\sum \text { Control }+\varepsilon_{i, t}
\end{gathered}
$$

Model 2: To test the relationship between corporate performance expectation gap and corporate asset divestiture frequency, the following models are established:

$$
\begin{gathered}
\text { Dives }_{i, t}=\beta_{0}+\beta_{1} \text { Fallh }_{i, t-1}+\sum \text { Control }+\varepsilon_{i, t} \\
\text { Dives }_{i, t}=\beta_{0}+\beta_{1} \text { Falli }_{i, t-1}+\sum \text { Control }+\varepsilon_{i, t}
\end{gathered}
$$

Model 3: To test the moderating effect of private benefits of control of management on the relationship between corporate performance expectation gap and corporate $\mathrm{M} \& \mathrm{~A}$ frequency, this paper adds the product term of private benefits of control and corporate performance expectation gap based on Model 1, and establishes the following two models:

$$
\begin{aligned}
& \operatorname{Acqui}_{i, t}= \\
& \beta_{0}+\beta_{1} \text { Fallh }_{i, t-1}+\beta_{3} \text { Fallh }_{i, t-1} \times \text { Perk }_{i, t-1}+\beta_{5} \text { Perk }_{i, t-1}+\sum{\text { Control }+\varepsilon_{i, t}}_{i, t} \\
& \text { Acqui }_{i, t}=\beta_{0}+\beta_{1} \text { Falli }_{i, t-1}+\beta_{3} \text { Fall }_{i, t-1} \times \text { Perk }_{i, t-1}+\beta_{5} \text { Perk }_{i, t-1}+\sum \text { Control } \\
& +\varepsilon_{i, t}
\end{aligned}
$$

Model 4: To test the moderating effect of private benefits of control of management on the relationship between corporate performance expectation gap and corporate asset divestiture frequency, this paper adds the product term of private benefits of control and corporate performance expectation gap based on Model 2, and establishes the following two models:

$$
\begin{array}{r}
\text { Dives }_{\mathrm{i}, \mathrm{t}}=\beta_{0}+\beta_{1} \text { Fallh }_{\mathrm{i}, \mathrm{t}-1}+\beta_{3} \text { Fallh }_{\mathrm{i}, \mathrm{t}-1} \times \text { Perk }_{\mathrm{i}, \mathrm{t}-1}+\beta_{5} \text { Perk }_{\mathrm{i}, \mathrm{t}-1}+\sum_{\mathrm{C} \text { Control }}+ \\
\varepsilon_{\mathrm{i}, \mathrm{t}} \\
\text { Dives }_{\mathrm{i}, \mathrm{t}}=\beta_{0}+\beta_{1} \text { Falli }_{\mathrm{i}, \mathrm{t}-1}+\beta_{3} \text { Falli }_{\mathrm{i}, \mathrm{t}-1} \times \text { Perk }_{\mathrm{i}, \mathrm{t}-1}+\beta_{5} \text { Perk }_{\mathrm{i}, \mathrm{t}-1}+\sum \text { Control }_{+}+ \\
\varepsilon_{\mathrm{i}, \mathrm{t}}
\end{array}
$$

Model 5: To test the moderating effect of managerial equity incentive on the relationship between corporate performance expectation gap and corporate M\&A frequency, this paper adds the product term of managerial equity incentive and corporate performance expectation gap based on Model 1, and establishes the following two models:

$$
\begin{gathered}
\text { Acqui }_{i, t}=\beta_{0}+\beta_{1} \text { Fallh }_{i, t-1}+\beta_{3} \text { Fall }_{i, t-1} \times \text { Incen }_{i, t-1}+\beta_{4} \text { Incen }_{i, t-1}+\sum \text { Control } \\
+\varepsilon_{i, t} \\
\text { Acqui }_{i, t}= \\
\beta_{0}+\beta_{1} \text { Falli }_{i, t-1}+\beta_{3} \text { Falli }_{i, t-1} \times \text { Incen }_{i, t-1}+\beta_{4} \text { Incen }_{i, t-1}+\sum \text { Control } \\
+\varepsilon_{i, t}
\end{gathered}
$$

Model 6: To test the moderating effect of managerial equity incentive on the relationship between corporate performance expectation gap and corporate asset stripping frequency, this paper adds the product term of managerial equity incentive and corporate performance expectation gap based on model 2 , and establishes the following two models: 


$$
\begin{aligned}
\text { Dives }_{i, t}= & \beta_{0}+\beta_{1} \text { Fallh }_{i, t-1}+\beta_{3} \text { Fall }_{i, t-1} \times \text { Incen }_{i, t-1}+\beta_{4} \text { Incen }_{i, t-1}+\text { Control } \\
& +\varepsilon_{i, t} \\
\text { Bives }_{i, t}= & \beta_{0}+\beta_{1} \text { Falli }_{i, t-1}+\beta_{3} \text { Falli }_{i, t-1} \times \text { Incen }_{i, t-1}+\beta_{4} \text { Incen }_{i, t-1}+\text { Control } \\
& +\varepsilon_{i, t}
\end{aligned}
$$

\section{Results}

\subsection{Descriptive Analysis}

Table 2 lists the descriptive statistical results of the main variables. From the table, the highest frequency of mergers and acquisitions Acqui is 20, the lowest is 0 , the average is 0.967 , and the standard deviation is 1.039 , indicating that the average frequency of mergers and acquisitions in this sample is still low, and the frequency of mergers and acquisitions varies greatly. The highest Dives stripping frequency was 12 , the lowest was 0 , and the average was 0.48 , indicating that many companies did not strip during the sample period.

Table 2. Descriptive Statistics of Main Variables

\begin{tabular}{cccccc}
\hline Variable & Obs & Mean & Std.Dev. & Min & Max \\
\hline Acqui & 2483 & 1.039 & 1.615 & 0 & 12 \\
Dives & 2483 & 0.573 & 1.118 & 0 & 0.981 \\
Fallh & 2483 & 0.023 & 0.051 & 0 & 1.036 \\
Falli & 2483 & 0.027 & 0.057 & 0.2 & 0.975 \\
Incen & 2483 & 0.481 & 0.195 & 0 & 0.357 \\
Perk & 2483 & 0.018 & 0.039 & 0.002 & 7.714 \\
Share & 2483 & 0.159 & 0.192 & 0.294 & 48.124 \\
Slack & 2483 & 1.423 & 1.914 & 16.757 & 27.146 \\
Size & 2483 & 21.696 & 1.145 & -27.854 & 205.89 \\
Debt & 2483 & 0.884 & 5.044 & 0 & 1.591 \\
Abovh & 2483 & 0.013 & 0.049 & 0 & 0.922 \\
Abovh & 2483 & 0.021 & 0.044 & $-8.01 \mathrm{e}+10$ & $6.25 \mathrm{e}+10$ \\
Freec & 2483 & $-1.13 \mathrm{e}+08$ & $3.42 \mathrm{e}+09$ & 6.597 & 9.65 \\
Lnage & 2483 & 8.52 & 0.398 & 0.453 & 1 \\
stata & 2483 & 0.289 & & 0
\end{tabular}

\subsection{Correlation Analysis}

Table 3 shows the correlation of the main variables in this paper. As shown in the table, the historical financial performance gap has a significant positive correlation with the frequency of M\&A and has no significant correlation with the frequency of stripping. The business financial performance gap has a significant positive

\begin{tabular}{|c|c|c|c|c|c|c|c|c|c|c|c|c|c|c|c|}
\hline Variable & (1) & (2) & (3) & (4) & (5) & (6) & (7) & (8) & (9) & (10) & (11) & (12) & (13) & (14) & (15) \\
\hline (1)Acqui & 1.000 & & & & & & & & & & & & & & \\
\hline (2)Dives & $0.087 *$ & 1.000 & & & & & & & & & & & & & \\
\hline (3)Fallh & $0.073^{*}$ & -0.027 & 1.000 & & & & & & & & & & & & \\
\hline (4)Falli & $0.139 *$ & $-0.071^{*}$ & $0.737 *$ & 1.000 & & & & & & & & & & & \\
\hline
\end{tabular}
correlation with the frequency of $M \& A$ and a significant negative correlation with the frequency of stripping.

Table 3. Correlation analysis of main variables 


\begin{tabular}{|c|c|c|c|c|c|c|c|c|c|c|c|c|c|c|}
\hline (5)Incen & $0.039 *$ & $0.035^{*}$ & -0.022 & $-0.053^{*}$ & 1.000 & & & & & & & & & \\
\hline (6)Perk & 0.018 & 0.010 & $0.107 *$ & $0.076^{*}$ & 0.033 & 1.000 & & & & & & & & \\
\hline (7)Share & $0.205^{*}$ & $0.080^{*}$ & $-0.109 *$ & $-0.042 *$ & $0.044^{*}$ & $-0.127 *$ & 1.000 & & & & & & & \\
\hline (8)Slack & $0.069 *$ & -0.033 & -0.027 & $0.080 *$ & $-0.119 *$ & $-0.068^{*}$ & $0.095 *$ & 1.000 & & & & & & \\
\hline (9)Size & $0.066^{*}$ & -0.006 & 0.037 & $0.101^{*}$ & -0.013 & 0.011 & $0.074 *$ & 0.035 & 1.000 & & & & & \\
\hline (10)Debt & 0.020 & $0.050 *$ & $-0.115^{*}$ & $-0.054^{*}$ & -0.032 & $0.046^{*}$ & $-0.078^{*}$ & $-0.038^{*}$ & 0.013 & 1.000 & & & & \\
\hline (11)Abovh & $-0.107 *$ & $0.072 *$ & $-0.076^{*}$ & $-0.238^{*}$ & $0.066^{*}$ & -0.016 & $-0.061 *$ & $-0.088^{*}$ & -0.032 & $0.448 *$ & 1.000 & & & \\
\hline (12)Abovi & 0.004 & -0.006 & -0.009 & -0.022 & 0.006 & 0.016 & $-0.057 *$ & $0.086^{*}$ & 0.007 & -0.001 & 0.016 & 1.000 & & \\
\hline (13)Freec & $-0.113^{*}$ & -0.013 & $0.062 *$ & $-0.090^{*}$ & -0.029 & $0.195^{*}$ & $-0.255^{*}$ & $-0.133^{*}$ & $-0.061 *$ & $-0.041^{*}$ & $0.106^{*}$ & -0.003 & 1.000 & \\
\hline (14)Lnage & $0.120^{*}$ & $-0.055^{*}$ & $-0.065^{*}$ & $0.067 *$ & 0.013 & -0.028 & $0.255^{*}$ & $0.118 *$ & $0.058^{*}$ & $0.042 *$ & $-0.077^{*}$ & $-0.046^{*}$ & $-0.211^{*}$ & 1.000 \\
\hline (15)stata & $0.092 *$ & $-0.072 *$ & $-0.091^{*}$ & $0.072 *$ & $-0.200 *$ & $-0.068^{*}$ & $0.280^{*}$ & $0.335^{*}$ & $0.082 *$ & 0.006 & $-0.105^{*}$ & -0.014 & $-0.162 *$ & $0.191 *$ \\
\hline
\end{tabular}

Note. $*$ in the table indicates significant at the $5 \%$ statistical level.

\subsection{Analysis of Regression Results}

Table 4 is the regression result of M\&A frequency as the dependent variable. According to the Hausman test results, this paper selects the fixed effect model to study the relationship between the two. It can be seen from Column (1) that there is a significant negative correlation between the gap in corporate the historical (financial) performance expectations and the frequency of $\mathrm{M} \& \mathrm{~A}$, and the regression coefficient is -1.519 , which is significant at the statistical level of $5 \%$. Column (4) shows that the relationship between the gap in corporate industry performance expectations and the frequency of M\&A is significantly negatively correlated, and the regression coefficient is -2.199 , which is significant at the $1 \%$ statistical level. This is fully consistent with our hypothesis 1a expectations, indicating that the greater the gap in corporate performance expectations, the lower the frequency of mergers and acquisitions.

To verify Hypothesis 2a, this paper uses the negative binomial regression to study the moderating effect of private benefits of management control on the gap between corporate performance expectations (performance evaluated is the financial) and corporate $M \& A$ frequency. Column (2) shows the moderating effect of private benefits of management control on corporate historical performance gap and corporate M\&A rate. In this column, the relationship between corporate historical performance expectation gap and corporate M\&A frequency is significantly negatively correlated. Although the interaction term Fallh*Perk adjusts the relationship between corporate historical performance expectation gap and corporate M\&A frequency in a direction consistent with expectations, it is not statistically significant. Column (5) shows the moderating effect of private benefits of management control on corporate industry performance gap and corporate M\&A rate. Although the interaction term Falli*Perk has a moderating effect on the relationship between corporate industry performance gap and corporate M\&A frequency, it is not statistically significant. In general, it fails to verify Hypothesis $2 \mathrm{a}$.

To test hypothesis $3 \mathrm{a}$, this paper uses negative binomial regression to study the moderating effect of managerial equity incentive on the relationship between corporate performance expectation gap and M\&A frequency. Column (3) shows the moderating effect of managerial equity incentive on corporate historical performance gap and corporate M\&A frequency. The relationship between corporate historical performance expectation gap and corporate M\&A frequency is not statistically significant. The coefficient of the interaction term Fallh*Incent is -116.018 , which is significant at the statistical level of $1 \%$, but the gap in corporate historical performance expectations is not significant in this model. Therefore, managerial equity incentive cannot positively regulate the relationship between the gap in corporate historical performance expectations and the frequency of corporate M\&A. Column (6) shows the moderating effect of managerial equity incentive on the relationship between the gap in corporate industry performance expectations and the frequency of M\&A. In this column, the relationship between the gap in corporate industry performance expectations and the frequency of M\&A is significantly negatively correlated. The interaction term Falli*Incent coefficient is -67.864 , which is significant at the statistical level of $5 \%$, and positively regulates the relationship between the gap in corporate industry performance expectations and the frequency of M\&A. In general, the moderating effect of managerial equity incentive on the gap between corporate performance expectations and the frequency of mergers and acquisitions is roughly consistent with expectations, which partially verifies the hypothesis $3 \mathrm{a}$. 
Table 4. Corporate performance expectation gap and M\&A rate

\begin{tabular}{|c|c|c|c|c|c|c|}
\hline \multirow{2}{*}{ variable } & (1) & (2) & (3) & (4) & (5) & (6) \\
\hline & Acqui & Acqui & Acqui & Acqui & Acqui & Acqui \\
\hline Fallh $_{i, t-1}$ & $\begin{array}{c}-1.519 * *(0.71 \\
6)\end{array}$ & $\begin{array}{c}-1.829 * *(0.9 \\
12)\end{array}$ & $-0.457(0.696)$ & & & \\
\hline Fall $_{i, t-1}$ & & & & $\begin{array}{c}-2.199 * * *(0.6 \\
90)\end{array}$ & $\begin{array}{c}-2.008 * *(0.86 \\
8)\end{array}$ & $\begin{array}{c}-1.506 * *(0.690 \\
)\end{array}$ \\
\hline$\underset{-1}{\text { Fallh }_{i, t-1}}$ Perk $_{i, t}$ & & $1.650(2.768)$ & & & & \\
\hline Falli $_{i, t-1} * \operatorname{Perk}_{i, t-}$ & & & & & $-1.169(3.391)$ & \\
\hline$\underset{\substack{\text { Fallh }_{i, t-1} \\
i, t-1}}{* \text { Incent }}$ & & & $\begin{array}{c}-116.018 * * *(32.9 \\
20)\end{array}$ & & & \\
\hline Falli $_{i, t-1}$ Incent $_{i}$ & & & & & & $\begin{array}{c}-67.864 * *(27.2 \\
56)\end{array}$ \\
\hline Incent $_{i, t-1}$ & $-0.706(0.903)$ & $-0.693(0.903)$ & $0.807(0.946)$ & $-0.799(0.845)$ & $-0.803(0.845)$ & $0.132(0.895)$ \\
\hline Perk $_{, t-1}$ & $-0.342(0.448)$ & $-0.474(0.523)$ & $-0.352(0.444)$ & $-0.313(0.404)$ & $-0.231(0.472)$ & $-0.350(0.405)$ \\
\hline $\operatorname{Size}_{i, t-1}$ & $-0.078(0.057)$ & $-0.078(0.057)$ & $-0.069(0.057)$ & $-0.087 *(0.050)$ & $\begin{array}{c}-0.087 *(0.050 \\
)\end{array}$ & $-0.081(0.050)$ \\
\hline Shrare $_{i, t-1}$ & $0.000(0.240)$ & $0.001(0.240)$ & $0.033(0.240)$ & $-0.005(0.222)$ & $-0.004(0.222)$ & $0.006(0.221)$ \\
\hline $\operatorname{Debt}_{i, t-1}$ & $-0.008(0.011)$ & $-0.008(0.012)$ & $-0.009(0.011)$ & $-0.007(0.012)$ & $-0.007(0.012)$ & $-0.007(0.011)$ \\
\hline$A b o v h_{i, t-1}$ & $0.020(0.479)$ & $0.019(0.475)$ & $0.069(0.475)$ & & & \\
\hline$A b o v i_{i, t-1}$ & & & & $0.625(0.502)$ & $0.630(0.503)$ & $0.590(0.505)$ \\
\hline Freec $_{i, t-1}$ & $-0.000(0.000)$ & $-0.000(0.000)$ & $-0.000(0.000)$ & $-0.000(0.000)$ & $-0.000(0.000)$ & $-0.000(0.000)$ \\
\hline Slack $_{i, t-1}$ & $\begin{array}{c}0.059 * * *(0.0 \\
23)\end{array}$ & $\begin{array}{c}0.059 * *(0.02 \\
3)\end{array}$ & $0.060 * * *(0.023)$ & $\begin{array}{c}0.044 * * *(0.01 \\
7)\end{array}$ & $\begin{array}{c}0.044 * * *(0.0 \\
17)\end{array}$ & $\begin{array}{c}0.045 * * *(0.017 \\
)\end{array}$ \\
\hline Lnage $_{i, t-1}$ & $0.388 *(0.221)$ & $\begin{array}{c}0.386 *(0.221 \\
)\end{array}$ & $0.361(0.224)$ & $\begin{array}{c}0.380 * *(0.181 \\
)\end{array}$ & $\begin{array}{c}0.381 * *(0.18 \\
0)\end{array}$ & $0.364 * *(0.180)$ \\
\hline Year $_{i, t}$ & Control & control & control & Control & control & control \\
\hline State $_{i, t-1}$ & control & control & control & control & control & control \\
\hline _Cons & control & control & control & control & control & control \\
\hline Obs. & 2483 & 2483 & 2483 & 2986 & 2986 & 2986 \\
\hline
\end{tabular}

Note. $* * *, * * *$ in the table are significant at $10 \%, 5 \%, 1 \%$, respectively.

Table 5 is the regression results with asset stripping frequency as the dependent variable. We make a regression on the gap between corporate performance expectations and the frequency of corporate asset divestiture, and add the private benefits of management control and equity incentives to adjust. In this table, the gap between corporate performance expectations includes the gap between historical performance expectations and the gap between industry performance expectations. According to the Hausman test results, this paper selects the fixed effect model to study the relationship between the two. It can be seen from Column (1) that the regression coefficient of the historical performance expectation gap is 1.535 , which is significant at the $1 \%$ statistical level. Column (4) shows that the regression coefficient of the performance expectation gap of enterprises is 1.713 , which is significant at the $1 \%$ statistical level. This is fully consistent with our hypothesis $1 \mathrm{~b}$ 's expectations, indicating that the greater the gap in corporate performance expectations, the higher the frequency of divestiture.

To verify Hypothesis $2 b$, this paper uses negative binomial regression to study the moderating effect of private benefits of management control on the relationship between performance expectation gap and corporate asset divestiture frequency. According to the results of column (2), the interaction Fallh*Perk coefficient is -4.502 , 
which is significant at a 5\% statistical level. It indicates that private benefits of control negatively moderate the relationship between the gap of corporate historical performance expectations and the frequency of corporate asset divestment. In column (5), the interaction term Falli*Perk coefficient is -4.115 , which is significant at the $10 \%$ statistical level. It indicates that private benefits of control negatively moderate the relationship between the gap of corporate industry performance expectations and the frequency of corporate asset divestment. In general, private benefits of management control negatively moderates the relationship between corporate performance expectation gap and corporate asset divestiture frequency, which is consistent with Hypothesis $2 \mathrm{~b}$.

To verify Hypothesis $3 b$, this paper uses the negative binomial regression to study the moderating effect of managerial equity incentive on the gap between corporate performance expectations and the frequency of corporate asset divestiture. Column (3) shows the moderating effect of managerial equity incentive on the relationship between corporate historical performance expectation gap and corporate asset divestiture frequency. The interaction term Fallh*Incent coefficient is 40.884 , which is significant at the $1 \%$ statistical level, but the corporate historical performance expectation gap is not significant in the model itself. Column (6) shows the moderating effect of managerial equity incentive on the relationship between corporate performance expectation gap and corporate asset divestiture frequency. In this column, the corporate financial performance expectation gap is positively correlated with corporate asset divestiture frequency, and the interaction term Falli*Incent coefficient is 26.434 , which is significant at the statistical level of $5 \%$. This indicates that equity incentive positively moderates the relationship between the gap of corporate industry performance expectations and the frequency of corporate asset divestment. Overall, managerial equity incentive positively moderates the relationship between corporate performance expectation gap and corporate asset divestiture frequency, partly in line with hypothesis $3 b$.

Table 5. Corporate performance expectation gap and corporate asset divestiture rate

\begin{tabular}{|c|c|c|c|c|c|c|}
\hline & (1) & (2) & (3) & (4) & (5) & (6) \\
\hline & Dives & Dives & Dives & Dives & Dives & Dives \\
\hline Fallh $_{i, t-1}$ & $\begin{array}{c}1.535^{* * * *}(0.570 \\
)\end{array}$ & $\begin{array}{c}2.663 * * *(0.694 \\
)\end{array}$ & $0.792(0.635)$ & & & \\
\hline Falls $_{i, t-1}$ & & & & $1.713 * * *(0.461)$ & $2.489 * * *(0.568)$ & $1.141 * *(0.529)$ \\
\hline Fallh $_{i, t-1} *$ Perk $_{i, t-1}$ & & $-4.502 * *(2.192)$ & & & & \\
\hline Falli $_{i, t-1} * \operatorname{Perk}_{i, t-1}$ & & & & & $-4.115^{*}(2.118)$ & \\
\hline Fallh $_{i, t-1} *$ Incent $_{i, t-}$ & & & $40.884^{* * *}(13.021$ & & & \\
\hline 1 & & & ) & & & \\
\hline Falli $_{i, t-1} *$ Incent $_{i, t-1}$ & & & & & & $\begin{array}{c}26.434 * *(10.932 \\
)\end{array}$ \\
\hline Incent $_{i, t-1}$ & $\begin{array}{c}4.864 * * *(1.190 \\
)\end{array}$ & $\begin{array}{c}4.815 * * *(1.183 \\
)\end{array}$ & $3.707 * * *(1.249)$ & $4.535 * * *(1.136)$ & $4.387 * * *(1.139)$ & $3.489 * * *(1.219)$ \\
\hline Perk $_{, t-1}$ & $0.222(0.176)$ & $0.244(0.150)$ & $0.216(0.167)$ & $0.216(0.176)$ & $0.974 * *(0.434)$ & $0.223(0.168)$ \\
\hline $\operatorname{Size}_{i, t-1}$ & $0.073(0.065)$ & $0.071(0.065)$ & $0.076(0.065)$ & $0.056(0.061)$ & $0.063(0.061)$ & $0.054(0.061)$ \\
\hline Shrare $_{i, t-1}$ & $0.493 *(0.270)$ & $0.467 *(0.270)$ & $0.433(0.271)$ & $0.359(0.257)$ & $0.359(0.257)$ & $0.335(0.257)$ \\
\hline $\operatorname{Debt}_{i, t-1}$ & $-0.000(0.004)$ & $-0.001(0.004)$ & $0.001(0.004)$ & $-0.001(0.004)$ & $-0.002(0.003)$ & $-0.001(0.004)$ \\
\hline Abovh $_{i, t-1}$ & $-0.550(0.785)$ & $-0.462(0.808)$ & $-0.559(0.864)$ & & & \\
\hline Abovi $_{i, t-1}$ & & & & $-3.184 * *(1.265)$ & $-3.082 * *(1.260)$ & $-3.227 * *(1.276)$ \\
\hline Freec $_{i, t-1}$ & $0.000(0.000)$ & $0.000(0.000)$ & $0.000(0.000)$ & $0.000(0.000)$ & $0.000(0.000)$ & $0.000(0.000)$ \\
\hline Slack $_{i, t-1}$ & $-0.119 * *(0.055)$ & $-0.116^{* *}(0.055)$ & $-0.124 * *(0.055)$ & $\begin{array}{c}-0.152 * * *(0.051 \\
)\end{array}$ & $\begin{array}{c}-0.156^{* * *}(0.052 \\
)\end{array}$ & $-0.160 * * *(0.052)$ \\
\hline Lnage $_{i, t-1}$ & $0.073(0.289)$ & $0.073(0.290)$ & $0.074(0.291)$ & $0.156(0.247)$ & $0.165(0.248)$ & $0.147(0.248)$ \\
\hline Year $_{i, t}$ & Control & control & Control & Control & control & Control \\
\hline State $_{i, t-1}$ & control & control & Control & control & control & Control \\
\hline
\end{tabular}




$\begin{array}{ccccccc}\text { CCons } & \text { control } & \text { control } & \text { Control } & \text { control } & \text { control } & \text { Control } \\ \text { Obs. } & 2157 & 2157 & 2157 & 2530 & 2530 & 2530\end{array}$

Note. $* * *, * * *$ in the table are significant at $10 \%, 5 \%, 1 \%$, respectively.

\subsection{Robustness Test}

The robustness test conforms to hypotheses $1 \mathrm{a}, 1 \mathrm{~b}, 2 \mathrm{~b}$, and $3 \mathrm{~b}$. In the previous empirical analysis, the enterprise historical performance expectations gap alpha choice is 0.6. To ensure the robustness of the research, in the robustness test, this paper selects $\alpha=0.5$ to replace $\alpha=0.6$ to calculate the historical performance expectation gap of enterprises. In addition, the matching object $\mathrm{k}$ adopted in this paper is five in the empirical research on the performance expectation gap of enterprises. In the robustness test, this paper selects three matching objects $\mathrm{k}=3$ to replace $\mathrm{k}=5$ to calculate the industry performance expectation gap of enterprises. The results are shown in Table 6 and Table 7 .

Table 6. Corporate performance expectation gap and M\&A rate

\begin{tabular}{|c|c|c|c|c|c|c|}
\hline & (1) & (2) & (3) & (4) & (5) & (6) \\
\hline Fallh $_{i, t-1}$ & $-1.749 * *(0.735)$ & $\begin{array}{c}-2.104 * *(0.943 \\
)\end{array}$ & $-0.700(0.718)$ & & & \\
\hline Falls $_{i, t-1}$ & & & & $-0.981 * *(0.490)$ & $-1.266^{*}(0.656)$ & $-0.989 *(0.529)$ \\
\hline Fallh $_{i, t-1} *$ Perk $_{i, t-1}$ & & $1.853(2.813)$ & & & & \\
\hline Falli $_{i, t-1} *$ Perk $_{i, t-1}$ & & & & & $1.941(2.843)$ & \\
\hline Fallh $_{i, t-1} *$ Incent $_{i, t-}$ & & & $-109.030 * * *(31.581$ & & & \\
\hline 1 & & & ) & & & \\
\hline Falli $_{i, t-1} *$ Incent $_{i, t-1}$ & & & & & & $0.385(9.513)$ \\
\hline Incent $_{i, t-1}$ & $-0.704(0.903)$ & $-0.690(0.903)$ & $0.862(0.958)$ & $-0.811(0.849)$ & $-0.816(0.848)$ & $-0.823(0.898)$ \\
\hline Perk $_{, t-1}$ & $-0.321(0.446)$ & $-0.468(0.526)$ & $-0.335(0.444)$ & $-0.431(0.395)$ & $-0.538(0.414)$ & $-0.431(0.395)$ \\
\hline Size $_{i, t-1}$ & $-0.081(0.057)$ & $-0.081(0.057)$ & $-0.072(0.057)$ & $-0.077(0.050)$ & $-0.077(0.050)$ & $-0.077(0.050)$ \\
\hline Shrare $_{i, t-1}$ & $0.003(0.240)$ & $0.003(0.240)$ & $0.034(0.240)$ & $-0.091(0.220)$ & $-0.091(0.220)$ & $-0.092(0.220)$ \\
\hline $\operatorname{Debt}_{i, t-1}$ & $-0.008(0.012)$ & $-0.008(0.012)$ & $-0.008(0.011)$ & $-0.008(0.010)$ & $-0.008(0.010)$ & $-0.008(0.010)$ \\
\hline Abovh $_{i, t-1}$ & $-0.103(0.534)$ & $-0.100(0.529)$ & $-0.066(0.532)$ & & & \\
\hline$A b o v i_{i, t-1}$ & & & & $-0.076(0.526)$ & $-0.096(0.526)$ & $-0.077(0.527)$ \\
\hline Freec $_{i, t-1}$ & $-0.000(0.000)$ & $-0.000(0.000)$ & $-0.000(0.000)$ & $-0.000(0.000)$ & $-0.000(0.000)$ & $-0.000(0.000)$ \\
\hline Slack $_{i, t-1}$ & $\begin{array}{c}0.059 * * *(0.023 \\
)\end{array}$ & $0.059 * *(0.023)$ & $0.060 * * *(0.023)$ & $\begin{array}{c}0.047 * * *(0.017 \\
)\end{array}$ & $\begin{array}{c}0.047 * * *(0.017 \\
)\end{array}$ & $\begin{array}{c}0.047 * * *(0.017 \\
)\end{array}$ \\
\hline Lnage $_{i, t-1}$ & $0.389 *(0.222)$ & $0.387 *(0.222)$ & $0.367(0.224)$ & $0.379 * *(0.180)$ & $0.376^{* *}(0.180)$ & $0.379 * *(0.180)$ \\
\hline Year $_{i, t}$ & Control & control & control & Control & control & control \\
\hline State $_{i, t-1}$ & control & control & control & control & control & control \\
\hline _Cons & control & control & control & control & control & control \\
\hline Obs. & 2483 & 2483 & 2483 & 2986 & 2986 & 2986 \\
\hline
\end{tabular}

Note. $* * *, * * *$ in the table are significant at $10 \%, 5 \%, 1 \%$, respectively. 
Table 7. Corporate performance expectation gap and corporate asset divestiture rate

\begin{tabular}{|c|c|c|c|c|c|c|}
\hline & (1) & (2) & (3) & (4) & (5) & (6) \\
\hline Fallh $_{i, t-1}$ & $\begin{array}{c}1.703^{* * * *}(0.554 \\
)\end{array}$ & $\begin{array}{c}2.792 * * *(0.668 \\
)\end{array}$ & $0.967(0.624)$ & & & \\
\hline Falls $_{i, t-1}$ & & & & $0.976 *(0.513)$ & $1.213 *(0.689)$ & $1.633 * * *(0.585)$ \\
\hline Fallh $_{i, t-1} * \operatorname{Perk}_{i, t-1}$ & & $-4.478 * *(2.131)$ & & & & \\
\hline Falli $_{i, t-1} * \operatorname{Perk}_{i, t-1}$ & & & & & $-1.052(2.083)$ & \\
\hline Fallh $_{i, t-1} *$ Incent $_{i, t-}$ & & & $38.160 * * *(12.807$ & & & \\
\hline l & & & ) & & & \\
\hline Falli $_{i,-1} *$ Incent $_{i, t-1}$ & & & & & & $\begin{array}{c}-30.577 *(16.634 \\
)\end{array}$ \\
\hline Incent $_{i, t-1}$ & $\begin{array}{c}4.863^{* * * *}(1.188 \\
)\end{array}$ & $\begin{array}{c}4.791 * * *(1.183 \\
)\end{array}$ & $3.714 * * *(1.253)$ & $4.459 * * *(1.155)$ & $4.459 * * *(1.155)$ & $5.554 * * *(1.256)$ \\
\hline Perk $_{t-1}$ & $0.224(0.178)$ & $0.245(0.151)$ & $0.216(0.169)$ & $0.228(0.169)$ & $0.397(0.379)$ & $0.238(0.172)$ \\
\hline Size $_{i, t-1}$ & $0.080(0.065)$ & $0.077(0.066)$ & $0.082(0.066)$ & $0.041(0.060)$ & $0.044(0.060)$ & $0.042(0.060)$ \\
\hline Shrare $_{i, t-1}$ & $0.494 *(0.270)$ & $0.464 *(0.271)$ & $0.441(0.271)$ & $0.488 *(0.258)$ & $0.486 *(0.258)$ & $0.490 *(0.257)$ \\
\hline $\operatorname{Debt}_{i, t-1}$ & $-0.000(0.004)$ & $-0.001(0.004)$ & $0.000(0.004)$ & $0.000(0.004)$ & $0.001(0.004)$ & $0.000(0.004)$ \\
\hline Abovh $_{i, t-1}$ & $-0.263(0.764)$ & $-0.177(0.795)$ & $-0.215(0.863)$ & & & \\
\hline$A b o v i_{i, t-1}$ & & & & $-0.568(0.737)$ & $-0.529(0.741)$ & $-0.497(0.741)$ \\
\hline Freec $_{i, t-1}$ & $0.000(0.000)$ & $0.000(0.000)$ & $0.000(0.000)$ & $0.000(0.000)$ & $0.000(0.000)$ & $0.000(0.000)$ \\
\hline Slack $_{i, t-1}$ & $-0.118 * *(0.055)$ & $-0.116^{* * *}(0.055)$ & $-0.123 * *(0.055)$ & $\begin{array}{c}-0.176^{* * * *}(0.053 \\
)\end{array}$ & $\begin{array}{c}-0.177 * * *(0.053 \\
)\end{array}$ & $\begin{array}{c}-0.175 * * *(0.053 \\
)\end{array}$ \\
\hline Lnage $_{i, t-I}$ & $0.069(0.289)$ & $0.070(0.290)$ & $0.071(0.291)$ & $0.203(0.246)$ & $0.203(0.246)$ & $0.185(0.246)$ \\
\hline Year $_{i, t}$ & Control & Control & Control & Control & Control & Control \\
\hline State $_{i, t-1}$ & Control & Control & Control & Control & Control & Control \\
\hline _Cons & Control & Control & Control & Control & Control & Control \\
\hline Obs. & 2157 & 2157 & 2157 & 2530 & 2530 & 2530 \\
\hline
\end{tabular}

Note: $* * *, * * *$ in the table are significant at $10 \%, 5 \%, 1 \%$, respectively.

\section{Conclusion}

\subsection{Conclusions and Discussion}

\subsubsection{Performance Expectation Gap and Strategic Change}

In this study, historical performance expectations (the performance evaluated is the financial) and industry performance expectations are negatively correlated with the frequency of mergers and acquisitions. The historical performance expectation gap and industry performance expectation gap are positively correlated with the asset stripping rate. When the enterprise's performance gap increases, that is, when the gap between the actual performance and the expected performance is large, the enterprise may face more severe resource constraints, and the risk that the management is willing to bear will decrease, and it is more inclined to implement the asset divestiture behavior of releasing resources. When the performance gap is small, the resource constraints faced by enterprises are weak, and management is more likely to adopt an M\&A strategy to deal with insufficient performance.

\subsubsection{The Moderating Effect of Private Benefits of Management Control}

The moderating effect of private benefits of management control on the relationship between corporate performance expectation gap and corporate $M \& A$ rate is not statistically significant, which does not verify the hypothesis of this paper. The main reasons include the following three aspects: First when the enterprise performance expectations gap is large, the enterprise faces strong internal resource constraints. Although 
frequent M\&A allows management to gain more control over private benefits, M\&A activities that consume resources pose too much risk to enterprises, and failure in M\&A decision-making results in much higher losses to enterprises and management than private benefits they can earn through M\&A activities.

Second, China's listed companies' information disclosure system is not perfect, some listed companies may disclose information loopholes and errors. Third, the data selected in this paper are the information technology industry. Although the sample size of this paper is large (a total of 363 enterprises), the development of China's information technology industry is relatively late, and the sample size in earlier years is small, which may have an impact on the research results.

Private benefits of management control negatively moderate the relationship between corporate historical performance expectation gap and corporate asset divestiture rate. Private benefits of management control negatively moderate the relationship between corporate industry performance expectation gap and corporate asset divestiture rate, which is consistent with the expectation of this paper.

\subsubsection{Management Equity Incentive as Moderating Effect}

The moderating effect of managerial equity incentive on the relationship between corporate performance expectation gap and corporate M\&A frequency is not statistically significant when measuring corporate performance expectation gap with corporate historical performance expectation gap, but is statistically significant when measuring corporate performance expectation gap with corporate industry performance expectation gap. This shows that managerial equity incentive positively moderates the relationship between the gap in corporate industry performance expectations and the frequency of $M \& A$, which partially verifies the hypothesis of this paper. The moderating effect of managerial equity incentive on the relationship between corporate performance expectation gap and asset stripping rate is not significant at the statistical level when measuring corporate performance expectation gap by historical performance expectation gap, but significant at the statistical level when measuring corporate performance expectation gap by industry performance expectation gap. It shows that managerial equity incentive positively moderates the relationship between industry performance expectation gap and asset stripping rate, which partially verifies the hypothesis of this paper. Equity incentives can better solve the problem that the interests of owners and operators are not the same under the separation of the two rights. In the face of the performance expectation gap, the management can be consistent with the interests of shareholders. The management equity incentive can positively regulate the relationship between the performance expectation gap of the enterprise industry and the M\&A rate and the asset stripping rate.

\subsection{Research Deficiencies and Future Prospects}

There are still some shortcomings in this paper. First, the performance expectation gap in this paper selects the most common historical performance expectation gap and industry performance expectation gap in the traditional performance feedback model. However, different industries and the same industry may have different actual performance expectations in different periods. The follow-up study can measure the performance expectation target value of the enterprise top management team more directly through a questionnaire survey or an executive interview. Second, when enterprises face a performance expectations gap, they can search for problems and improve corporate performance through a variety of strategic change methods. This paper only considers the most typical M\&A and stripping in resource consumption strategy and resource release strategy. Future research can further explore more strategic change methods, such as integration, diversification, transformation, or reorganization.

\section{Funding}

This research is supported by the National Social Science Foundation of China (No.20BJY110) and the Social Science Program of Shandong Province (Collaborative Innovation Research On Major Theoretical and Practical Problems)(No.21CGLJ22).

\section{Acknowledgements}

The authors would like to thank the reviewers for their valuable comments. Gratitude is also extended to all authors of literatures cited in this article. 


\section{References}

Armstrong, C. S., Larcker, D. F., Ormazabal, G., \& Taylor, D. J. (2013). The relation between equity incentives and misreporting: The role of risk-taking incentives. Journal of Financial Economics, 109(2), 327-350. https://doi.org/10.1016/j.jfineco.2013.02.019

Audia, P. G., \& Greve, H. R. (2006). Less likely to fail: Low performance, firm size, and factory expansion in the shipbuilding industry. Management science, 52(1), 83-94. https://doi.org/10.1287/mnsc.1050.0446

Berry, H. (2010). Why do firms divest? Organization science, 21(2), 380-396 https://doi.org/10.1287/orsc.1090.0444

Chen, W. R., \& Miller, K. D. (2007). Situational and institutional determinants of firms' R\&D search intensity. Strategic management journal, 28(4), 369-381. https://doi.org/10.1002/smj.594

del Carmen Triana, M., Richard, O. C., \& Su, W. (2019). Gender diversity in senior management, strategic change, and firm performance: Examining the mediating nature of strategic change in high tech firms. Research Policy, 48(7), 1681-1693. https://doi.org/10.1016/j.respol.2019.03.013

D'Souza, J., \& Nash, R. (2017). Private benefits of public control: Evidence of political and economic benefits of state ownership. Journal of Corporate Finance, 46, 232-247. https://doi.org/10.1016/j.jcorpfin.2017.07.001

Fiegenbaum, A., \& Thomas, H. (1990). Strategic groups and performance: the US insurance industry, 1970-84. Strategic Management Journal, 11(3), 197-215. https://doi.org/10.1002/smj.4250110303

Fiegenbaum, A., \& Thomas, H. (1995). Strategic groups as reference groups: Theory, modeling and empirical examination of industry and competitive strategy. Strategic Management Journal, 16(6), 461-476. https://doi.org/10.1002/smj.4250160605

Hass, L. H., Tarsalewska, M., \& Zhan, F. (2016). Equity incentives and corporate fraud in China. Journal of Business Ethics, 138(4), 723-742. https://doi.org/10.1007/s10551-015-2774-2

Herrmann, P., \& Nadkarni, S. (2014). Managing strategic change: The duality of CEO personality. Strategic management journal, 35(9), 1318-1342. https://doi.org/10.1002/smj.2156

Hope, O. K., Wu, H., \& Zhao, W. (2017). Blockholder exit threats in the presence of private benefits of control. Review of Accounting Studies, 22(2), 873-902. https://doi.org/10.1007/s11142-017-9394-2

Hung, M. W., Liu, Y. J., \& Tsai, C. F. (2012). Managerial personal diversification and portfolio equity incentives. Journal of Corporate Finance, 18(1), 38-64. https://doi.org/10.1016/j.jcorpfin.2011.09.006

Iyer, D. N., \& Miller, K. D. (2008). Performance feedback, slack, and the timing of acquisitions. Academy of Management Journal, 51(4), 808-822. https://doi.org/10.5465/AMJ.2008.33666024

Jayaraman, S., \& Milbourn, T. (2015). CEO equity incentives and financial misreporting: The role of auditor expertise. The Accounting Review, 90(1), 321-350. https://doi.org/10.2308/accr-50854

Jordan, A. H., \& Audia, P. G. (2012). Self-enhancement and learning from performance feedback. Academy of management review, 37(2), 211-231. https://doi.org/10.5465/amr.2010.0108

Kim, M., Boyd, D. E., Kim, N., \& Cheong, H. Y. (2016). CMO equity incentive and shareholder value: Moderating role of CMO managerial discretion. International journal of research in marketing, 33(4), 725-738. https://doi.org/10.1016/j.ijresmar.2016.09.001

Kim, T., \& Rhee, M. (2017). Structural and behavioral antecedents of change: Status, distinctiveness, and relative performance. Journal of Management, 43(3), 716-741. https://doi.org/10.1177/0149206314541150

Kuusela, P., Keil, T., \& Maula, M. (2017). Driven by aspirations, but in what direction? Performance shortfalls, slack resources, and resource-consuming vs. resource-freeing organizational change. Strategic management journal, 38(5), 1101-1120. https://doi.org/10.1002/smj.2544

Lant, T. K., Milliken, F. J., \& Batra, B. (1992). The role of managerial learning and interpretation in strategic persistence and reorientation: An empirical exploration. Strategic management journal, 13(8), 585-608. https://doi.org/10.1002/smj.4250130803

Li, D. S. (2020). Research on interest mechanism reconstruction and effective governance mode in mixed ownership reform of large state-owned enterprises in China. Beijing: Economic Science House.

Markides, C. C. (1992). Consequences of corporate refocusing: Ex ante evidence. Academy of Management journal, 35(2), 398-412. https://doi.org/10.5465/256379 
March, J. G. (1963). A behavioral theory of the firm. Englewood Cliffs, NJ: Prentice-Hall.

Masoud, N. (2017). An empirical study of audit expectation-performance gap: The case of Libya. Research in International Business and Finance, 41, 1-15. https://doi.org/10.1016/j.ribaf.2017.04.012

Muravyev, A., Berezinets, I., \& Ilina, Y. (2014). The structure of corporate boards and private benefits of control: Evidence from the Russian stock exchange. International Review of Financial Analysis, 34, 247-261. https://doi.org/10.1016/j.irfa.2014.03.008

Oehmichen, J., Schrapp, S., \& Wolff, M. (2017). Who needs experts most? B oard industry expertise and strategic change-a contingency perspective. Strategic Management Journal,38(3), 645-656. https://doi.org/10.1002/smj.2513

Peng, M. W. (2003). Institutional transitions and strategic choices. Academy of management review, 28(2), 275-296. https://doi.org/10.5465/amr.2003.9416341

Quigley, T. J., \& Hambrick, D. C. (2012). When the former CEO stays on as board chair: Effects on successor discretion, strategic change, and performance. Strategic Management Journal,33(7), 834-859. https://doi.org/10.1002/smj.1945

Shimizu, K. (2007). Prospect theory, behavioral theory, and the threat-rigidity thesis: Combinative effects on organizational decisions to divest formerly acquired units. Academy of Management Journal, 50(6), 1495-1514. https://doi.org/10.5465/amj.2007.28226158

Sauerwald, S., Heugens, P. P., Turturea, R., \& Van Essen, M. (2019). Are all private benefits of control ineffective? Principal-Principal benefits, external governance quality, and firm performance. Journal of Management Studies, 56(4), 725-757. https://doi.org/10.1111/joms.12420

Wang, W., \& Wu, Y. (2020). Managerial control benefits and takeover market efficiency. Journal of Financial Economics, 136(3), 857-878. https://doi.org/10.1016/j.jfineco.2019.11.003

Zhang, X., Liang, X., \& Sun, H. (2013). Individualism-collectivism, private benefits of control, and earnings management: A cross-culture comparison. Journal of Business Ethics, 114(4), 655-664. https://doi.org/10.1007/s10551-013-1711-5

\section{Copyrights}

Copyright for this article is retained by the author(s), with first publication rights granted to the journal.

This is an open-access article distributed under the terms and conditions of the Creative Commons Attribution license (http://creativecommons.org/licenses/by/4.0/). 